\title{
D-Tagatose production by Lactococcus lactis NZ9000 Cells Harboring Lactobacillus plantarum L-arabinose Isomerase
}

\author{
Yao Zhang, Yanli Fan, Haijie Hu, Haixu Yang, Xuegang Luo, Zhongyuan Li, Hao Zhou, \\ Wenjian Ma, Yajian Song*, Tongcun Zhang
}

Key Laboratory of Industrial Fermentation Microbiology, Ministry of Education, Tianjin Industrial Microbiology Key Laboratory, College of Biotechnology, Tianjin University of Science and Technology, Tianjin, People's Republic of CHINA.

\begin{abstract}
D-tagatose is a functional sweetener present in medicine, food, and dairy products and with broad market prospects, and L-arabinose isomerase gene (araA) can mediate the bioconversion of D-galactose into D-tagatose. In this study, a Lactococcus lactis NZ9000 strain harboring exogenous L-arabinose isomerase was constructed to produce D-tagatose. Lactobacillus plantarum CGMCC 8198 exhibits L-arabinose isomerase activity and its genome has been sequenced. The araA gene of Lactobacillus plantarum CGMCC 8198 encoding L-arabinose isomerase was identified by sequence analysis and was successfully cloned and expressed in Lactococcus lactis NZ9000. The D-tagatose production by the whole cell of the recombinant strain was optimized. The optimal condition for conversion reaction was at $50^{\circ} \mathrm{C}, \mathrm{pH} 7.0$ and with $300 \mathrm{mmol} / \mathrm{L} \mathrm{Mn}^{2+}$ and $60 \mathrm{~g} / \mathrm{L}$ galactose added. The D-tagatose yield and conversion rate at the optimal condition was determined and reached $40.2 \mathrm{~g} / \mathrm{L}$ and $67 \%$, respectively.
\end{abstract}

Key words: D-tagatose, L-arabinose isomerase, Lactococcus lactis NZ9000, Lactobacillus plantarum, Galactose.

\section{INTRODUCTION}

D-tagatose, a unique and rare hexoketose monosaccharide, is a C4 epimer of D-fructose and an isomer of aldohexose D-galactose. D-tagatose naturally occurs in a small amount of Sterculia setigera gum ${ }^{1}$ and dairy products, ${ }^{2}$ such as hot cocoa, ${ }^{3}$ various cheeses and yogurts, ${ }^{4}$ ultra-high-temperature (UHT) lactose-hydrolyzed milk. ${ }^{5}$ The sweetness of $\mathrm{D}$-tagatose is almost equivalent to sucrose but with a lower calorific value at $1.5 \mathrm{kcal} / \mathrm{g}$ for humans. ${ }^{6}$ Furthermore, it has many health and medical benefits, such as antioxidant, prebiotic, and tooth friendly properties. D-tagatose has the GRAS (Generally Recognized as Safe) status granted by the US Food and Drug Administration (FDA), and was currently tested as a potentially important new drug for treating type II diabetes and obesity. ${ }^{7,9}$ In recent years,
D-tagatose has been drawing great attention as a non-caloric sweetener substitute for sucrose, ${ }^{10,11,12}$ as well as considerable commercial use.

D-tagatose can be synthesized from D-galactose through chemical or enzymatic way. The production of $\mathrm{D}$-tagatose was first achieved by chemical method, using calcium catalyst and strong acid. ${ }^{13}$ However, the chemical method has many drawbacks, such as byproduct, chemical waste formation and high energy-consuming. ${ }^{14}$ In the enzymatic method, L-arabinose isomerase (L-AI) is the most efficient enzyme for isomerizing D-galactose to D-tagatose. ${ }^{15}$ Generally, a major consideration in biotransformation processes is the development suitable biological catalysts. ${ }^{16,17}$ L-AI from various prokaryotic microbes have been identified,
Submission Date: 30-08-2016; Revision Date: 17-11-2016; Accepted Date: 23-11-2016

DOI: 10.5530/ijper.51.2.34 Correspondence: Yajian Song, College of Biotechnology, Tianjin University of Science and Technology,

No. 29, 13th Street Tianjin Economic and Technological Development Area, Tianjin 300457, CHINA. Telephone: +862260601104 Fax: +862260600518 E-mail: songyajian@tust. edu.cn

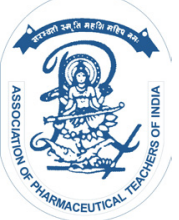

www.ijper.org 
including those from Escherichia coli, ${ }^{18}$ Lactobacillus plantarum, ${ }^{19,20}$ Lactobacillus fermentum, ${ }^{21}$ Artbrobacter sp. ${ }^{22}$ Lactobacillus sakei, ${ }^{23}$ Bifidobacterium longum, ${ }^{24}$ and Thermus sp. Strain. ${ }^{25}$

Lactococcus lactis is one of the best-characterized GRAS microorganisms and an efficient expression host for the heterologous proteins. It is a good candidate for different biotechnological applications related to food products, such as D-tagatose production. This paper reports the expression of L-arabinose isomerase gene ( $\operatorname{ara} A)$ from Lactobacillus plantarum CGMCC 8198 in Lactococcus lactis NZ9000. The result shows that recombinant L. lactis cells, harboring the Lactobacillus plantarum L-AI enzyme, produce D-tagatose efficiently after the conversion condition optimization.

\section{MATERIALS AND METHODS}

\section{Plasmid and strains}

Lactobacillus plantarum CGMCC 8198, Lactobacillus acidophilus 1.1859, Lactobacillus acidophilus 1.2686, Lactobacillus casei 1.2435, Lactobacillus casei 1.539, Lactobacillus sake 23K, Bifidobacterium infantis, Bifidobacterium bifidum ATCC29521, were stored at laboratory and cultured anaerobically at $37^{\circ} \mathrm{C}$ in MRS broth. Escherichia coli $\mathrm{DH} 5 \alpha$ was used as a host for the construction of expression vectors, which was grown in LB medium and supplemented with ampicillin $(100 \mu \mathrm{g} / \mathrm{mL})$ at $37^{\circ} \mathrm{C}$ with rotary shaking at $200 \mathrm{rpm}$ or on LB medium solidified with $1.5 \%$ (w/v) agar. L. lactis NZ9000 was cultivated at $30^{\circ} \mathrm{C}$ in M17 medium with $2 \%$ (w/v) glucose. Nisin, $10 \mathrm{ng} / \mathrm{mL}$, was used for inducing the expression of L-AI. Chloramphenicol was used at a concentration of $10 \mu \mathrm{g} / \mathrm{mL}$ for the selection of the expressed vector PCYT (China Pharmaceutical University).

\section{Selection of strain with high L-Al activity}

8 Lactic acid bacteria strains were cultured for $24 \mathrm{~h}$ and harvested by centrifugation (10000 $\mathrm{g}$ for $20 \mathrm{~min}$ ). The cells were suspended by $10 \mathrm{~mL}$ sodium phosphate buffer (200 mmol/L pH7.0), disrupted by sonication $(150 \mathrm{~W}$; working time, $4 \mathrm{~s}$; interval, $4 \mathrm{~s}$, cooling temperature, $4^{\circ} \mathrm{C}$ ), and centrifuged with $10000 \mathrm{~g}$ for $1 \mathrm{~min}$ at $4^{\circ} \mathrm{C}$. The supernatant was collected and used as crude enzyme.

$0.5 \mathrm{~mL}$ crude enzyme and $1.0 \mathrm{~mL}$ galactose $(500 \mathrm{mmol} / \mathrm{L})$ was reacted for $1 \mathrm{~h}$ at $60^{\circ} \mathrm{C}$. And then the reaction was terminated with $0.5 \mathrm{~mL} \mathrm{HCl}(100 \mathrm{mmol} / \mathrm{L})$. The generated D-tagatose was determined by the cysteine-carbazolsulfuric acid method, with the absorbance of $560 \mathrm{~nm}$. The concentration of D-tagatose was calibrated on the basis of the standard linear graph prepared using different D-tagatose concentrations. One unit of L-AI activity was defined as the amount of enzyme catalyzing the formation of D-tagatose $(1 \mu \mathrm{g} / \mathrm{min})$ under optimal conditions.

\section{Cloning of araA gene from Lactobacillus plantarum CGMCC 8198 and construction of recombinant plasmid}

The genome of Lactobacillus plantarum CGMCC 8198 has been sequenced in our previous study, and its araA was identified by gene annotation. The oligonucleotides P1 (5'-CCAATGCATCAATGTTATCAGTACCTGATTATGAGT-3') and P2 (5'-ATCTGTCTAAGCT'TTTACT'T'TAAGAATGCCT'TAGTC-3') were used for PCR amplification of araA gene. The restriction endonuclease NsiI and HindIII sites were incorporated into the primer P1 and P2 respectively. The purified PCR product were digested with $N s i \mathrm{I}$ and HindIII and inserted into pCYT. Sequentially, the resulted plasmid pCYT-araA was transformed into E.coli DH5 $\alpha$ for cloning and then isolated and transformed into L. lactis NZ9000 for expression.

\section{Overexpression of L-Al isomerase in L. lactis NZ9000}

The obtained recombinant strain L. lactis NZ9000pCTY-araA was inoculated to $10 \mathrm{~mL}$ of GM17 medium supplemented with $10 \mathrm{mg} / \mathrm{mL}$ chloramphenicol. $10 \mathrm{ng} / \mathrm{mL}$ nisin was added to induce the protein expression when $\mathrm{OD}_{600}$ reached 0.6. After the nisin was added, the culture was cultivated at $30^{\circ} \mathrm{C}$ overnight. The cells were harvested by centrifugation (10000 $\mathrm{g}$ for $20 \mathrm{~min}$ ), resuspended by $10 \mathrm{~mL} 200 \mathrm{mM}$ sodium phosphate buffer ( $\mathrm{pH} 7.0$ ), and disrupted by sonication (150 W; working time, $4 \mathrm{~s}$; interval, $4 \mathrm{~s}$; and cooling temperature, $\left.4^{\circ} \mathrm{C}\right)$. The supernatant was obtained and treated as crude enzyme. The L-AI activity of the crude enzyme was determined as description above and the protein expression was analyzed by sodium dodecyl sulfate-polyacrylamide gel electrophoresis (SDS-PAGE).

Effect of temperature, $\mathrm{pH}$, metal ions, and substrate concentration on tagatose production

L. lactis NZ9000-pCTY-araA was cultured and induced as description above, and the cells were harvested and resuspended by $200 \mathrm{mmol} / \mathrm{L}$ sodium phosphate buffer $(\mathrm{pH} 7.0)$ to $\mathrm{OD}_{600}$ of 0.6 for $\mathrm{D}$-tagatose production. The basic reaction condition was as follows: the reaction system was supplemented with $100 \mathrm{~g} / \mathrm{L}$ D-galactose, $100 \mathrm{mmol} / \mathrm{L} \mathrm{Mn}^{2+}$ and incubated at $50^{\circ} \mathrm{C}$ for $96 \mathrm{~h}$.

The D-tagatose production was measured when the reaction proceeded for $48 \mathrm{~h}-120 \mathrm{~h}$ as description above. The effect of temperature was determined by measuring the D-tagatose production after the reaction buffer was incubated at different temperature $\left(30-70^{\circ} \mathrm{C}\right)$ at 
pH7.0 for $96 \mathrm{~h}$. The effect of $\mathrm{pH}$ was determined by measuring the $\mathrm{D}$-tagatose production when the reaction was at $\mathrm{pH}$ 6.0-9.0 using sodium phosphate buffer incubated at $50^{\circ} \mathrm{C}$ for $96 \mathrm{~h}$. The effect of metal ion was determined by measuring the concentration of D-tagatose when the reaction system was added with $100 \mathrm{mmol} / \mathrm{L}$ of $\mathrm{Mg}^{2+}, \mathrm{Ca}^{2+}, \mathrm{Cu}^{2+}, \mathrm{Fe}^{2+}, \mathrm{K}^{+}, \mathrm{Li}^{+}, \mathrm{Ni}^{2+}$, $\mathrm{Zn}^{2+}, \mathrm{Co}^{2+}, \mathrm{Mn}^{2+}$ respectively and incubated at $\mathrm{pH} 7.0$ and $50^{\circ} \mathrm{C}$ for $96 \mathrm{~h}$. Additionally, the effect of substrate and $\mathrm{Mn}^{2+}$ concentration to $\mathrm{D}$-tagatose yield was determined by adding galactose with various concentration of $20-100 \mathrm{~g} / \mathrm{L}$ and $\mathrm{Mn}^{2+}$ with various concentration of 50-500 $\mathrm{mmol} / \mathrm{L}$.

\section{Multifactor optimization of the D-tagatose production}

The condition of $\mathrm{D}$-tagatose production by $L$. lactis NZ9000-pCTY-araA cells was optimized. The experimental design is shown in Table 1. Design Expert 8.0 software was used for constructing the experiment designs and performing the statistical analysis. The four variables used were temperature between 40 and $60^{\circ} \mathrm{C}, \mathrm{pH}$ between 6.0 and 8.0, substrate concentration between 20 and $100 \mathrm{~g} / \mathrm{L}$, and $\mathrm{Mn}^{2+}$ concentration between $100 \mathrm{mmol} / \mathrm{L}$ and $500 \mathrm{mmol} / \mathrm{L}$. The D-galactose yield and the conversion ratio of $\mathrm{D}$-galactose to $\mathrm{D}$-tagatose were calculated and all the samples were incubated for $96 \mathrm{~h}$.

\section{RESULTS}

\section{Cloning and sequence analysis of gene encoding araA from Lactobacillus plantarum CGMCC 8198}

The crude L-AI activity of 8 wild Lactic acid bacteria was determined, and the result was shown in Figure 1. Lactobacillus plantarum CGMCC 8198 exhibits the highest activity of L-AI and was chosen as the donor of araA gene (Figure 1). The araA gene of 1450 bp encoding 483 amino acid from L. plantarum CGMCC 8198 was successfully cloned. The gene exhibited homology of $99 \%$ to that from Lactobacillus plantarum strain JBE245 (EMBL accession number CP014780) and Lactobacillus plantarum strain ZS2058 (EMBL accession number CP012343), 95\% to that from Lactobacillus paraplantarum strain L-ZS9 (EMBL accession number CP013130) and $86 \%$ to that from Lactobacillus pentosus MP-10 (EMBL accession number FR871824). The sequence of araA was shown in supplementary material Text S1.

\section{Overexpression of L-AI in L. Lactis NZ9000}

L-AI from L. plantarum CGMCC 8198 was ligased with pCYT to construct the recombinant expression plasmid pCYT-araA (Figure 2). L-AI expression strain L. lactis

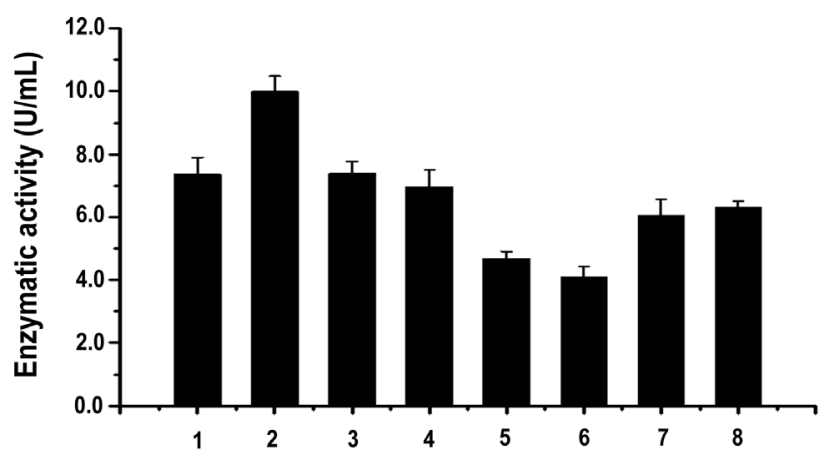

Figure 1: The L-Al activity of 8 lactic acid bacteria. 1: Lactobacillus casei 1.539; 2: Lactobacillus plantarum CGMCC 8198; 3: Lactobacillus acidophilus 1.2686; 4: Lactobacillus acidophilus 1.1859; 5: Bifidobacterium. Infantis; 6: Lactobacillus sakei 23K; 7: Lactobacillus casei 1.2435; 8: Bifidobacterium bifidum ATCC 29521.

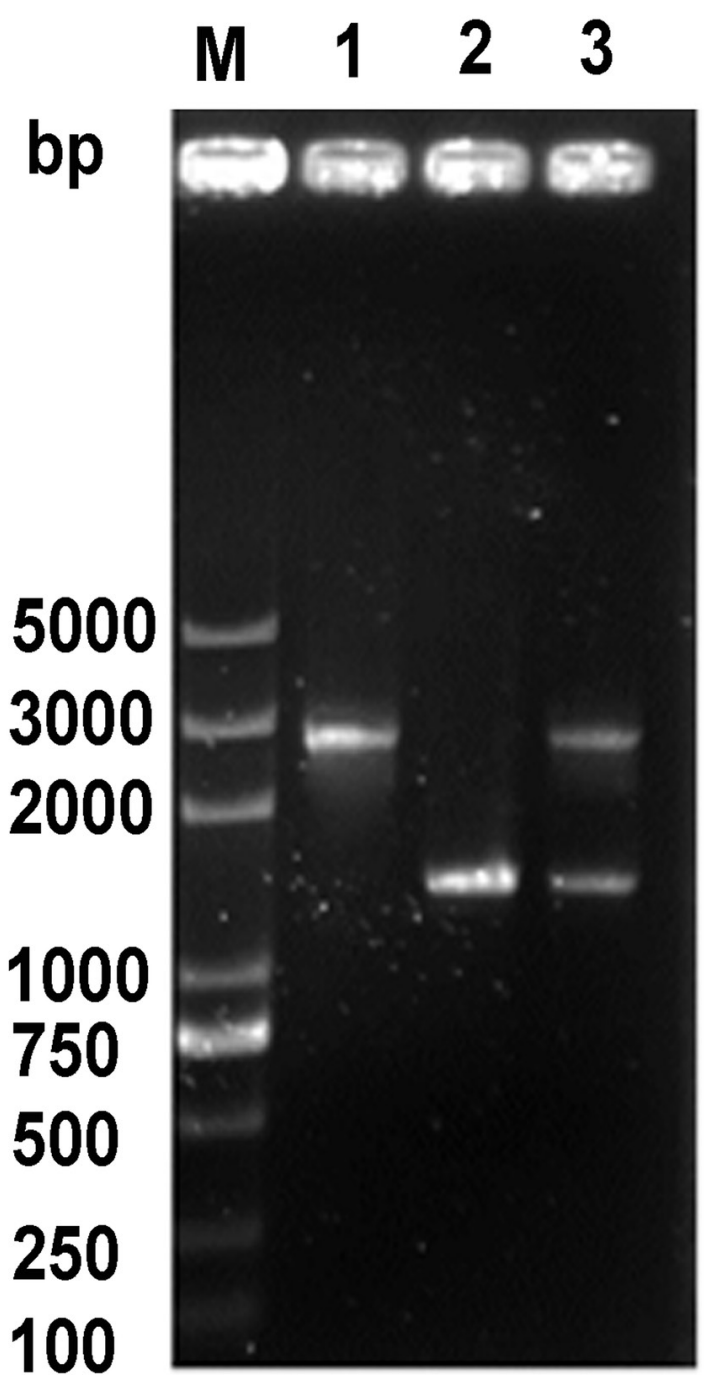

Figure 2: PCR detection of pCYT-araA. M: Marker; 1: pCYT digested by Nsil and Hindlll; 2: araA amplified by PCR; 3: PCYT-araA degested by Nsil and Hindlll. 


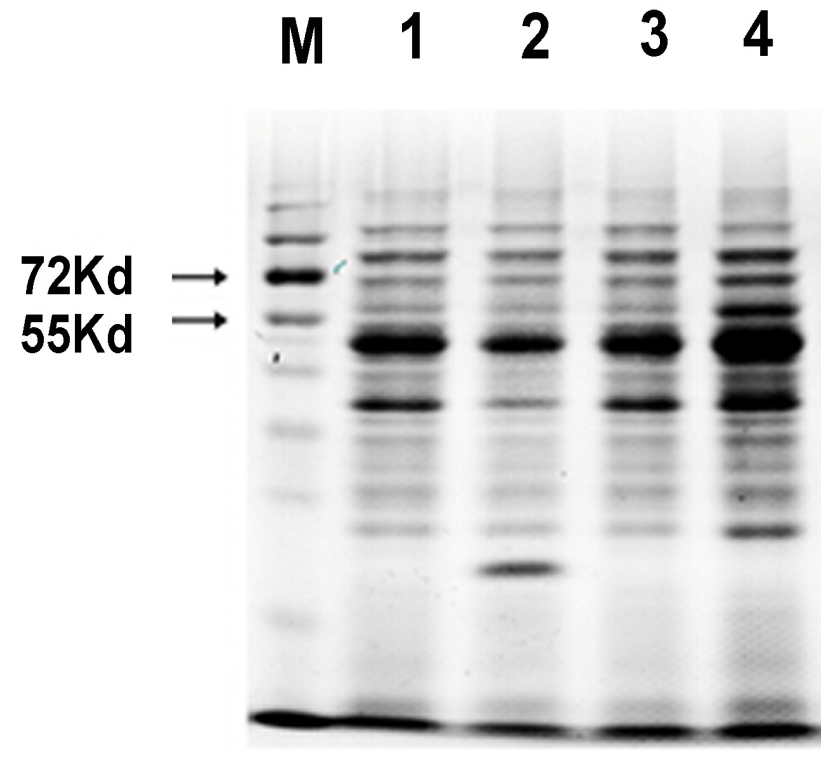

Figure 3: SDS-PAGE analysis of the expression of AraA by L. lactis NZ9000. M: Marker; 1: L. lactis NZ9000 with PCYT without induction by ninsin; 2: L. lactis NZ9000 with PCYT with induction by ninsin; 3: L. lactis NZ9000 with pCYT-araA without induction by ninsin; 4: L. lactis NZ9000 with pCYTaraA with induction by ninsin.
A

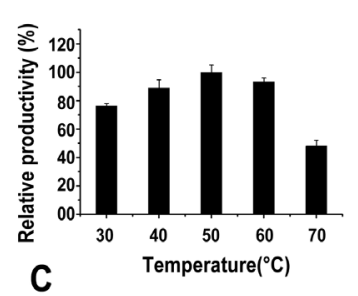

D
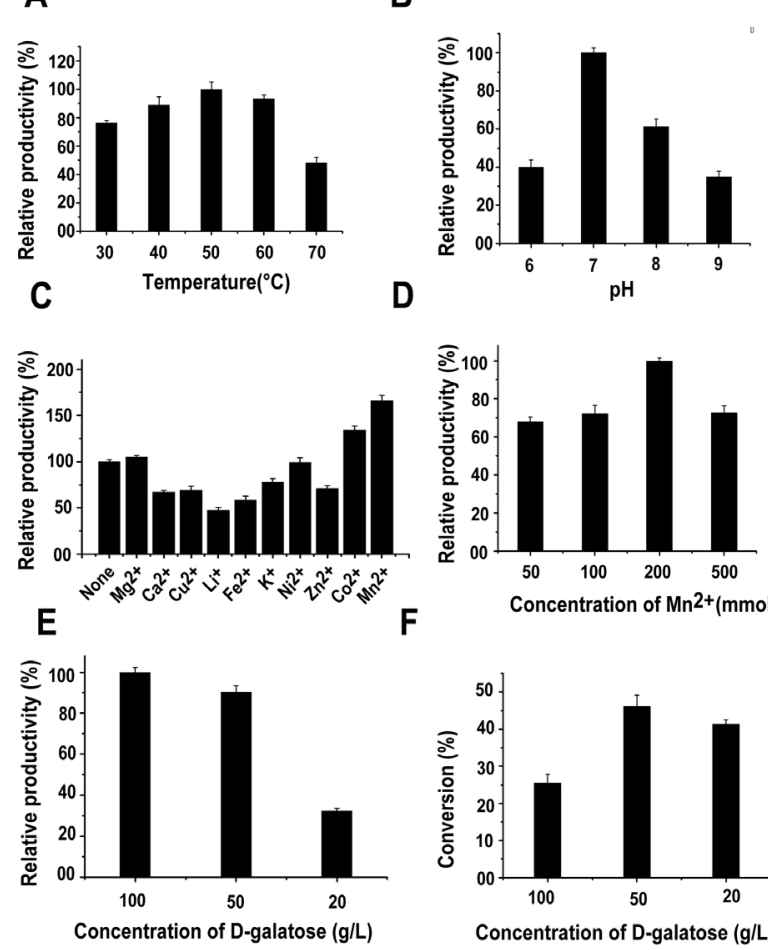

$\mathbf{F}$
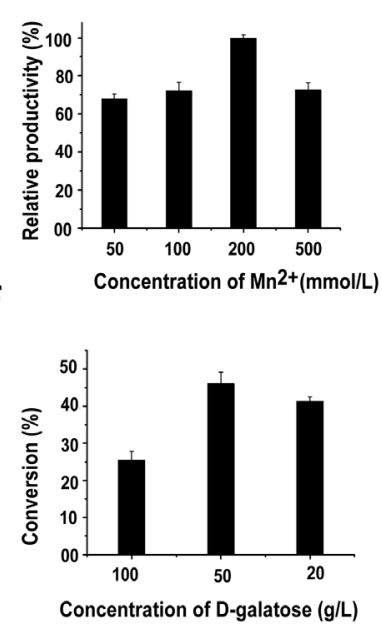

Figure 4: Effect of temperature, $\mathrm{pH}$, metal ions, and substrate concentration on tagatose production. A: The relative productivity at different temperature; $\mathrm{B}$ : The relative productivity at different $\mathrm{pH}$; $\mathrm{C}$ : The relative productivity with different ions added; D: The relative productivity with different concentration of $\mathrm{Mn}^{2+}$ added; $\mathrm{E}$ : The relative productivity with different concentration of D-galactose added; F : The conversion with different concentration of D-galactose added.

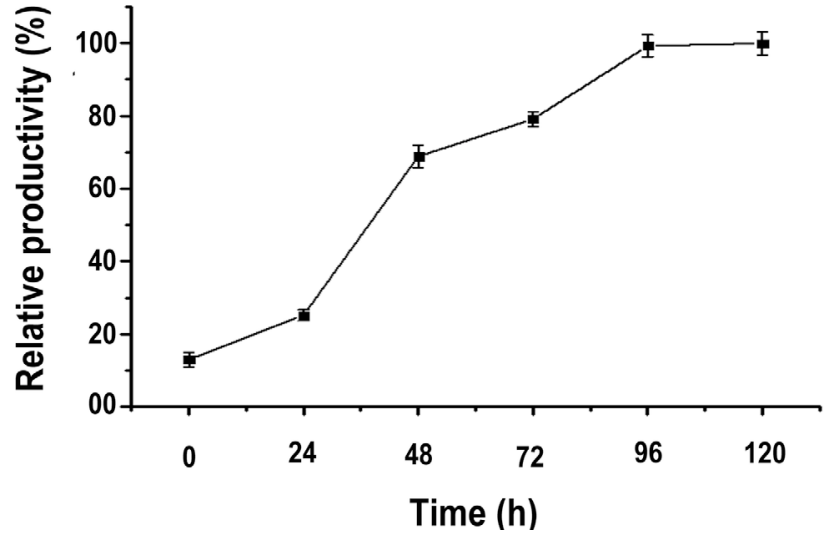

Figure 5: The relative productivity of D-tagatose at differnt time.

NZ9000-pCTY-araA was successfully constructed by inducing $\mathrm{pCY}$ T-araA harboring L-AI from $L$. plantarum CGMCC 8198 to L. lactis NZ9000. The expression of the protein was detected by $10 \%$ SDS-PAGE (Figure 3). As expected, the results showed that the L-AI with theoretical molecular weight of $53 \mathrm{kD}$ was successfully expressed in the host. The activity of L-AI was detected in the supernatant of cell lysate and reached $47 \mathrm{U} / \mathrm{mL}$.

Effect of temperature, $\mathrm{pH}$, metal ions, and substrate concentration on tagatose production

The influence of the different factors on D-tagatose production by the recombinant strain was shown in Figure 4. The optimum temperature for the $\mathrm{D}$-tagatose production was $50^{\circ} \mathrm{C}$ (Figure $4 \mathrm{~A}$ ) and the optimum $\mathrm{pH}$ was 7.0(Figure 4B). Compared with otherions, the addition of $\mathrm{Mn}^{2+}$ dramatically promoted the reaction (Figure 4C). The effect of $\mathrm{Mn}^{2+}$ concentration was also investigated, and the result showed that the highest yield was obtained when $200 \mathrm{mmol} / \mathrm{L} \mathrm{Mn}^{2+}$ was added (Figure 4D). The substrate concentration not only affected the yield of D-tagatose but also affected the conversion rate. Figure $4 \mathrm{E} \& \mathrm{~F}$ showed that the D-tagatose yield was improved when the addition of galactose increased from $20 \mathrm{~g} / \mathrm{L}$ to $100 \mathrm{~g} / \mathrm{L}$. However, the conversion rate reached the peak when $50 \mathrm{~g} / \mathrm{L}$ galactose was added. Figure 5 showed that the D-tagatose production was continuously increasing from $0 \mathrm{~h}$ to $96 \mathrm{~h}$, and the yield at $96 \mathrm{~h}$ and $120 \mathrm{~h}$ has no remarkable difference. So, $96 \mathrm{~h}$ was chosen as the optimum reaction time.

\section{Multifactor optimization of the D-tagatose production}

The experimental design of multifactor optimization is shown in Table 1. Finally, the $\mathrm{D}$-tagatose production by Lactococcus lactis NZ9000 reached the highest when the bioconversion was at $50^{\circ} \mathrm{C}, \mathrm{pH} 7.0$, and with $60 \mathrm{~g} / \mathrm{L}$ D-galactose and $300 \mathrm{mmol} / \mathrm{L} \mathrm{Mn}^{2+}$ added. The highest 


\begin{tabular}{|c|c|c|c|c|c|c|c|}
\hline Std & Run & $\begin{array}{c}\text { A:Temperature } \\
\left({ }^{\circ} \mathrm{C}\right)\end{array}$ & B:pH & C: $\mathrm{Mn}^{2+}(\mathrm{mmol} / \mathrm{L})$ & $\begin{array}{c}\text { D: Substrate } \\
\text { concentration } \\
(g / L)\end{array}$ & $\begin{array}{l}\text { Productivity } \\
\text { (g/L) }\end{array}$ & $\begin{array}{c}\text { Conversion } \\
(\%)\end{array}$ \\
\hline 19 & 1 & 40.00 & 7.00 & 500.00 & 60.00 & 21.8 & 36.4 \\
\hline 23 & 2 & 50.00 & 6.00 & 300.00 & 100.00 & 25.0 & 25.0 \\
\hline 1 & 3 & 40.00 & 6.00 & 300.00 & 60.00 & 23.6 & 39.3 \\
\hline 12 & 4 & 60.00 & 7.00 & 300.00 & 100.00 & 28.2 & 28.2 \\
\hline 2 & 5 & 60.00 & 6.00 & 300.00 & 60.00 & 25.7 & 42.9 \\
\hline 7 & 6 & 50.00 & 7.00 & 100.00 & 100.00 & 21.3 & 21.3 \\
\hline 16 & 7 & 50.00 & 8.00 & 500.00 & 60.00 & 25.5 & 42.5 \\
\hline 17 & 8 & 40.00 & 7.00 & 100.00 & 60.00 & 20.7 & 34.6 \\
\hline 9 & 9 & 40.00 & 7.00 & 300.00 & 20.00 & 10.8 & 54.4 \\
\hline 27 & 10 & 50.00 & 7.00 & 300.00 & 60.00 & 40.2 & 67.0 \\
\hline 15 & 11 & 50.00 & 6.00 & 500.00 & 60.00 & 23.3 & 38.9 \\
\hline 25 & 12 & 50.00 & 7.00 & 300.00 & 60.00 & 36.3 & 60.5 \\
\hline 20 & 13 & 60.00 & 7.00 & 500.00 & 60.00 & 25.5 & 42.5 \\
\hline 5 & 14 & 50.00 & 7.00 & 100.00 & 20.00 & 10.1 & 50.6 \\
\hline 26 & 15 & 50.00 & 7.00 & 300.00 & 60.00 & 37.9 & 63.2 \\
\hline 14 & 16 & 50.00 & 8.00 & 100.00 & 60.00 & 32.8 & 54.7 \\
\hline 10 & 17 & 60.00 & 7.00 & 300.00 & 20.00 & 11.2 & 56.1 \\
\hline 3 & 18 & 40.00 & 8.00 & 300.00 & 60.00 & 25.5 & 42.5 \\
\hline 29 & 19 & 50.00 & 7.00 & 300.00 & 60.00 & 38.6 & 64.4 \\
\hline 28 & 20 & 50.00 & 7.00 & 300.00 & 60.00 & 40.2 & 67.0 \\
\hline 22 & 21 & 50.00 & 8.00 & 300.00 & 20.00 & 13.8 & 69.4 \\
\hline 24 & 22 & 50.00 & 8.00 & 300.00 & 100.00 & 27.3 & 27.3 \\
\hline 21 & 23 & 50.00 & 6.00 & 300.00 & 20.00 & 12.5 & 62.5 \\
\hline 18 & 24 & 60.00 & 7.00 & 100.00 & 60.00 & 24.7 & 41.2 \\
\hline 8 & 25 & 50.00 & 7.00 & 500.00 & 100.00 & 28.2 & 28.2 \\
\hline 4 & 26 & 60.00 & 8.00 & 300.00 & 60.00 & 27.8 & 46.4 \\
\hline 13 & 27 & 50.00 & 6.00 & 100.00 & 60.00 & 17.3 & 28.9 \\
\hline 6 & 28 & 50.00 & 7.00 & 500.00 & 20.00 & 10.3 & 51.6 \\
\hline 11 & 29 & 40.00 & 7.00 & 300.00 & 100.00 & 20.7 & 20.7 \\
\hline
\end{tabular}

production was $40.2 \mathrm{~g} / \mathrm{L}$ and the conversion of D-galactose to D-tagatose was $67 \%$.

\section{DISCUSSION}

D-tagatose is a functional sweetener present in food, ${ }^{26}$ dairy products and medicine with broad market prospects. ${ }^{27}$ The aim of this work was to investigate the possibility of producing D-tagatose from D-galactose with the recombinant Lactococcus lactis NZ9000 cells harboring araA from lactic acid bacteria. As described previously, the recombinant strain was successfully constructed and D-tagatose is produced efficiently after optimization.
The araA was derived from L. plantarum CGMCC 8198 whose genome has been sequenced and exhibiting L-AI activity. The sequence of the L-AI protein exhibited high homology to that of other L-AIs, suggesting that these genes might have evolved from a common ancestor. The mesophilichomo-fermentative bacterium Lactococcus lactis NZ9000 is an important industrial microorganism, ${ }^{28}$ which has GRAS (generally regarded as safe) status. The availability of technology for genetic and metabolic engineering of Lactococcus lactis NZ9000 combined with a long history of safe usage opened opportunities for applicationsin modern biotechnological applications especially as a heterologous expression host. ${ }^{29}$ So, Lactococcus lactis NZ9000 is a good candidate 
to express L-AI from lactic acid bacteria to produce D-tagotose.

In this study, we use the whole cell of the recombinant strain to produce $\mathrm{D}$-tagotose, which make the production process more facility. It is also the first report to produce D-tagotose by Lactococcus lactis NZ9000. The conversion reaction performed at high temperatures offers several advantages such as high conversion yield and fast reaction rate, and the moderate-high temperature is appropriate in industry production. The optimum temperature of the conversion reaction by the recombinant strain was $50^{\circ} \mathrm{C}$, suggesting that it has potential in industrial use. The optimum $\mathrm{pH}$ of the conversion reaction was 7.0, which is accordant with the most L-AIs reported. The reaction converting aldoses into corresponding ketoses often uses $\mathrm{Mn}^{2+}$ as a cofactor and in this study $\mathrm{Mn}^{2+}$ was determined to indeed enhance the D-tagatose yield.

By multifactor optimization, the optimal condition of D-tagatose production was obtained, and the yield and conversion rate were determined. Also the productivity is relatively low compared with some recombinant E. coli strains reported, Lactococcus lactis NZ9000 has its own advantage. As a GRAS strain it is more suitable to produce $\mathrm{D}$-tagatose which is mainly used in medicine and food area. However, in this study, the antibiotics chloramphenicol still should be added in the media in order to maintain the recombinant plasmid, and in the future we will attempt to integrate the exogenous gene into the genome of Lactococcus lactis NZ9000 to avoid the usage of antibiotics.

\section{CONCLUSION}

D-tagatose has broad market prospects in medicine and food industry. In this study we constructed a recombinant D-tagatose producing stain by introducing L-arabinose isomerase from Lactobacillus plantarum to Lactococcus lactis NZ9000. After multifactor optimization, the D-tagatose yield and conversion rate reached $40.2 \mathrm{~g} / \mathrm{L}$ and $67 \%$ respectively. This study is the first report to produce D-tagotose by Lactococcus lactis NZ9000.

\section{ACKNOWLEDGMENT}

This work was supported by the Tianjin Research Program of Application Foundation and Advanced Technology (NO. 14JCZDJC33200), and the Hi-tech Research and Development Program of China (863 Program) (NO. 2012AA021505 and NO. 2012AA022108).

\section{CONFLICT OF INTEREST}

No conflict of interest are declared.

\section{REFERENCES}

1. Hirst E L, Hough L, Jones J K. Composition of the gum of Sterculia setigera; occurrence of D-tagatose in nature. Nature. 1949;163(4135):177-82. https:// doi.org/10.1038/163177b0 PMid:18213788.

2. Jarald E E, Sharma S, Sheeja E, Ahmad S, Patni S, Daud A. Characterization of Moringa oleifera Lam. gum to establish it as a pharmaceutical excipient. Indian J Pharm Educ Res. 2012;46(3):211-6.

3. Andrews G R, Prasad S K. Effect of the protein, citrate and phosphate content of milk on formation of lactulose during heat treatment. J Dairy Res. 1987;54(2):207-18. https://doi.org/10.1017/S0022029900025358.

4. Levin G V, Zehner L R, Saunders J P, Beadle J R. Sugar substitutes: their energy values, bulk characteristics, and potential health benefits. Am J Clin Nutr. 1995;62(5):1161-8.

5. Mendoza M R, Olano A, Villamiel M. Chemical indicators of heat treatment in fortified and special milks. J Agric Food Chem. 2005;53(8):2995-9. https:// doi.org/10.1021/jf040406I PMid:15826050.

6. Kim P. Current studies on biological tagatose production using L-arabinose isomerase: a review and future perspective. Appl Microbiol Biotechnol. 2004;65(3):243-9. https://doi.org/10.1007/s00253-004-1665-8 PMid:15248040.

7. Lu Y, Levin G V, Donner T W. Tagatose, a new antidiabetic and obesity control drug. Diabetes Obes Metab. 2008;10(2):109-34. PMid:17941870.

8. Mason E E. Dumping for type-2 diabetes. J Obes Metab Res. 2015;2(1):3-4. https://doi.org/10.4103/2347-9906.148593.

9. Mehta P, Bhajoni P S, Mehta S P. Fighting cancer through an informed society. JOSH-Diabetes. 2016;4(2):57-66. https://doi.org/10.4103/23210656.187996.

10. Zehner LR. D-tagatose as a low-calorie carbohydrate sweetener and bulking agent. US: Elsevier. 1988. PMCid:PMC338509.

11. MazurA W. Functional sugar substitutes with reduced calorie. U.S. Patent 1992;5(106):14-21.

12. Tandel K R. Sugar substitutes: Health controversy over perceived benefits. J Pharmacol Pharmacother. 2011;2(4):236-43. https://doi.org/10.4103/0976500X.85936 PMCid:PMC3198517.

13. Beadle J R, Saunders J P, Wajda T J. Process for manufacturing tagatose. New York: Harper and Row. 1991.

14. Oh D K. Tagatose: properties, applications, and biotechnological processes. Appl Microbiol Biotechnol. 2007;76(1):1-8. https://doi.org/10.1007/s00253007-0981-1 PMid:17492284.

15. Cheetham P S J, Wootton AN. Bioconversion of D-galactose into D-tagatose. Enzyme Microb Technol. 1993;15(2):105-8. https://doi.org/10.1016/01410229(93)90032-W.

16. Kim H J, Ryu S A, Kim P, Oh D K. A feasible enzymatic process for D-tagatose production by an immobilized thermostable L-arabinose isomerase in a packed-bed bioreactor. Biotechnol Prog. 2003;19(2):400-4. https://doi. org/10.1021/bp025675f.

17. Sekhon B S, Jairath S. Prebiotics, probiotics and synbiotics: an overview. Indian J Pharm Educ Res. 2010;1(2):13-8.

18. Yoon S H, Kim P, Oh D K. Properties of L-arabinose isomerase from Escherichia coli as biocatalyst for tagatose production. World J Microbiol Biotechnol. 2003;19(1):47-51. https://doi.org/10.1023/A:1022575601492.

19. Chouayekh H, Bejar W, Rhimi M K Mseddi, Bejar S. Characterization of an L-arabinose isomerase from the Lactobacillus plantarum NC8 strain showing pronounced stability at acidic pH. FEMS Microbiol Lett. 2007;277(2):260-7. https://doi.org/10.1111/j.1574-6968.2007.00961.x PMid:18031349.

20. Seo B J, Bajpai V K, Rather I A, Park Y H. Partially purified exopolysaccharide from Lactobacillus plantarum YML009 with total phenolic content, antioxidant and free radical scavenging efficacy. Indian J Pharm Educ Res. 2015;49(4):282-92. https://doi.org/10.5530/ijper.49.4.6.

21. $\quad X u Z$, Qing $L, Y L i$, Feng $X, X u H$, Ouyang $P$. A novel L-arabinose isomerase from Lactobacillus fermentum CGMCC2921 for D-tagatose production: Gene 
cloning, purification and characterization. J Mol Catal B Enzym. 2011;70(1):1-7. https://doi.org/10.1016/j.molcatb.2011.01.010.

22. Wanarska M, Kur J. A method for the production of D-tagatose using a recombinant Pichiapastoris strain secreting $\beta$-D-galactosidase from Arthrobacter chlorophenolicus and a recombinant L-arabinose isomerase from Arthrobacter. Microb Cell Fact. 2012;11(1):1-15. https://doi. org/10.1186/1475-2859-11-113 PMid:22917022 PMCid:PMC3520711.

23. Rhimi M, IlhammamiR, Bajic G, Boudebbouze S, Maguin E, Haser R, Aghajari $\mathrm{N}$. The acid tolerant $\mathrm{L}$-arabinose isomerase from the food grade Lactobacillus sakei $23 \mathrm{~K}$ is an attractive D-tagatose producer. Bioresour Technol. 2010;101(23):9171-7. https://doi.org/10.1016/j. biortech.2010.07.036 PMid:20688514

24. Salonen N, Nyyssölä A, Salonen K, Turunen O. Bifidobacterium longum L-arabinose isomerase-overexpression in Lactococcus lactis, purification, and characterization. Appl Biochem Biotechnol. 2012;168(2):392-405. https://doi.org/10.1007/s12010-012-9783-8 PMid:22763951.
25. KimJW, RohHJ, Kim HY, ChaJH etal.Production of tagatose by a recombinant thermostable L-arabinose isomerase from Thermus sp. Biotechnol Lett. 2003;25(12):963-67. https://doi.org/10.1023/A:1024069813839 PMid:12889832.

26. Salonen N, Salonen K, Leisola M, Nyyssölä A. D-Tagatose production in the presence of borate by resting Lactococcus lactis cells harboring Bifidobacterium longum L-arabinose isomerase. Bioprocess Biosyst Eng 2012;36(4):489-97. https://doi.org/10.1007/s00449-012-0805-2.

27. Molinagutierrez A, Stippl V, Delgado A, Gänzle M G, Vogel R F. In situ determination of the intracellular $\mathrm{pH}$ of Lactococcus lactis and Lactobacillus plantarum during pressure treatment. Appl Environ Microbiol. 2002;68(9):4399-406. https://doi.org/10.1128/AEM.68.9.4399-4406.2002 PMCid:PMC124068.

28. De Ruyter P G, Kuipers O P, De Vos W M. Controlled gene expression systems for Lactococcus lactis with the food-grade inducer nisin. Appl Environ Microbiol. 1996;62(10):3662-7. PMid:8837421 PMCid:PMC168174.

29. Kuipers O, Oscar P. Quorum sensing-controlled gene expression in lactic acid bacteria. J Biotechnol. 1998;64(1):15-21. https://doi.org/10.1016/S01681656(98)00100-X

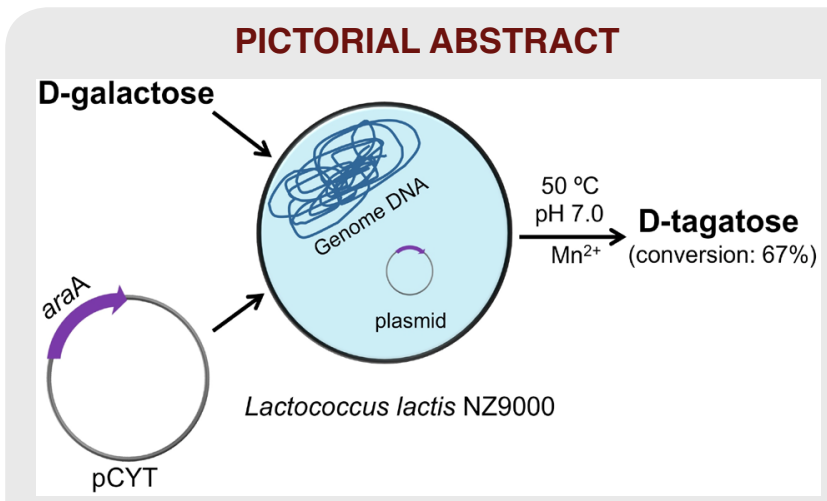

\section{SUMMARY}

- A D-tagatose producing stain was constructed by introducing L-arabinose isomerase gene from Lactobacillus plantarum to Lactococcus lactis NZ9000.

- After multifactor optimization, the D-tagatose yield and conversion rate reached $40.2 \mathrm{~g} / \mathrm{L}$ and $67 \%$ respectively.

- This study is the first report to produce D-tagotose by Lactococcus lactis NZ9000.

\section{About Authors}

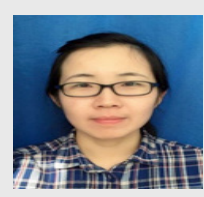

Yao Zhang: Obtained her Bachelor Degree at Nankai University in 2013 and completed her graduate study under the supervision of Prof. Tongcun Zhang at College of Biotechnology, Tianjin University of Science \& Technology in 2016. Her current research interests focus on the D-tagatose production by the enzymatic method.

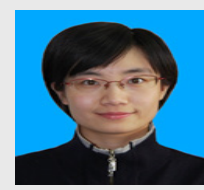

Dr. Yajian Song: Is a lecture of College of Biotechnology, Tianjin University of Science \& Technology. Her research interests focus on microbial physiology and biotechnology and has several $\mathrm{SCl}$ and El publications.

Cite this article: Zhang Y, Fan Y, Hu H, Yang H, Luo X, Li Z, Zhou H, Ma W, Song Y, Zhang T. D-Tagatose production by Lactococcus lactis NZ9000 Cells Harboring Lactobacillus plantarum L-arabinose Isomerase. Indian J of Pharmaceutical Education and Research. 2017;51(2):288-94. 